\title{
Effects of Aeschynomene histrix Poir. seed treatment on germination
}

\author{
Bignon Daniel Maxime Houndjo ${ }^{(1)}$, Sébastien Adjolohoun ${ }^{(1)}$, \\ Dourossimi Adam Adenile ${ }^{(1)}$, Marcel Houinato ${ }^{(1)}$, Brice Augustin Sinsin ${ }^{(2)}$
}

(1) Université d'Abomey-Calavi. Faculté des Sciences Agronomiques. École des Sciences et Techniques de Production Animale.03 BP 2819 Jéricho, Cotonou (Bénin).E-mail: houndjobignon@gmail.com

(2) Université d'Abomey-Calavi. Faculté des Sciences Agronomiques. École de l'Aménagement et de Gestion des Ressources Naturelles. 03 BP 2819 Jéricho, Cotonou (Bénin).

Received 4 March 2021, accepted 10 November 2021, available online 15 November 2021.

This article is distributed under the terms and conditions of the CC-BY License (http://creativecommons.org/licenses/by/4.0)

Description of the subject. Poor germination associated with physical dormancy was experienced in the legume Aeschynomene histrix Poir. seeds and can reduce the establishment and growth of this species.

Objectives. To evaluate the effects of different pre-planting treatments, including digestion by Lagune cattle or other preplanting treatments on the germinability of A. histrix seeds.

Method. The experiment was divided into three phases. Firstly, six Lagune cattle (three young bulls and three heifers) were fed individually with 1,000 seeds and these seeds were subsequently collected from faeces. Secondly, seed germination was compared among seeds defecated by cattle and seeds submitted to seven other pre-planting treatments: control (intact untreated seeds); seeds scarified using sandpaper; and seeds immersed in $80^{\circ} \mathrm{C}$-hot water for 2, 4, 6, 8, and $10 \mathrm{~min}$. Thirdly, we also assessed the effect of crumbling cattle faeces on A. histrix germinability.

Results. The results show that Lagune cattle can disperse seeds of A. histrix with maximum recovery on the second day after ingestion. Of the number of seeds fed $13.42 \%$ were recovered. The germination percentage was greatest for sandpaper scarified seeds (96\%) and seeds pre-heated during $2 \mathrm{~min}(86 \%)$, but least for digested seeds (4.27\%). Breaking-down the dung doubled seedling emergence from digested seeds.

Conclusions. As it is desirable to break dormancy of A. histrix seeds, the use of mechanical scarification using sandpapering or hot water scarification $80^{\circ} \mathrm{C}$ at 2 min may be more beneficial than cattle digestion.

Keywords. Scarification, endozoochory, thermal treatment, physical dormancy, Benin.

Effets des traitements des semences d'Aeschynomene histrix Poir. sur la germination

Description du sujet. La levée et la croissance d'Aeschynomene histrix Poir. peut être réduite à cause d'une dormance tégumentaire.

Objectifs. Évaluer les effets du temps de rétention des graines dans le tube digestif des bovins Lagunaires ou d'autres traitements pré-semis sur l'aptitude germinative des graines d'A. histrix.

Méthode. Premièrement, trois jeunes taureaux et trois génisses ont reçu individuellement 1000 graines qui ont été recherchées dans les excréments. Deuxièmement, la germination des graines excrétées par les bovins a été comparée à sept autres traitements pré-semis : contrôle (graines intactes non traitées); graines scarifiées au papier à scarifier et graines immergées dans de l'eau chaude $\left(80^{\circ} \mathrm{C}\right)$ pendant $2,4,6,8$ et $10 \mathrm{~min}$. Troisièmement, nous avons comparé le nombre de plantules qui ont émergé de fèces intactes et émiettées.

Résultats. Les bovins Lagunaires peuvent potentiellement favoriser la dispersion des graines d'A. histrix avec une récupération maximale le deuxième jour après l'ingestion. Sur le nombre de graines ingérées, 13,42\% ont été récupérées. Le pourcentage de germination était le plus élevé pour les graines scarifiées au papier à scarifier (96\%) et pour les graines préchauffées pendant $2 \min (86 \%)$, et le moins élevé pour celles issues du tractus digestif $(4,27 \%)$. La décomposition des excréments a doublé la levée des plantules.

Conclusions. Pour la levée de dormance des graines d'A. histrix, l'utilisation d'une scarification mécanique à l'aide du papier à scarifier ou le trempage des graines dans de l'eau chaude pendant 2 min peuvent être plus bénéfiques que l'ingestion par les bovins.

Mots-clés. Scarification, endozoochorie, traitement thermique, dormance physique, Bénin. 


\section{INTRODUCTION}

The legume (Fabaceae) Aeschynomene histrix (Poir.) is used for pasture improvement in Benin (Tarawali et al., 1988; Peters et al., 1994; Merkel et al., 2000; Adjolohoun, 2008; Houndjo et al., 2019a). However poor germination associated with physical dormancy was experienced in A. histrix seeds and can reduce the establishment of this species resulting in uneven establishment (Baskin \& Baskin, 1998; Bhatt et al., 2008). Researchers have noted that the hard seeds of many legumes species can be scarified after passing through the digestive tract of cattle, increasing germination capacity and speed (Pakeman et al., 2002; Campos et al., 2008). As it is desirable to break dormancy of legume seeds and contribute to the rehabilitation of degraded grassland in Benin, biological methods such as ingestion by Lagune cattle, mechanical scarification, or hot water treatment, may be of value (Ocumpaugh \& Swakon, 1993; Rusdy, 2015; Houndjo et al., 2019b). Our study focused on four main questions:

- are Lagune cattle acting as dispersal vectors for A. histrix?;

- how does seed retention time in the digestive tract affect seed germination?;

- what is the efficiency of treatments with hot water and mechanical scarification on the germination of untreated seeds, compared to cattle digestion?;

- how does breaking down the dung affect the seedling emergence of digested seeds?

\section{MATERIALS AND METHODS}

\subsection{Seed material}

The investigation involved three complementary activities and morphological characteristics of A. histrix seeds used are shown in table 1.

\subsection{Seeds retrieved after cattle digestion}

The seed-feeding experiment took place during two periods (from January 2019 to April 2019 and from December 2019 to March 2020). Six cattle (Bos taurus),

Table 1. Pods, seeds, and shells weight of Aeschynomene histrix used in the study - Poids des gousses, graines et enveloppes d'Aeschynomene histrix utilisées dans l'étude.

\begin{tabular}{lll}
\hline Parameter & Average & Range \\
\hline 1,000 pods weight $(\mathrm{g})$ & 1.84 & $1.65-1.99$ \\
1,000 seeds weight $(\mathrm{g})$ & 1.27 & $1.17-1.36$ \\
1,000 shells weight $(\mathrm{g})$ & 0.56 & $0.48-0.63$ \\
\hline
\end{tabular}

Source: Houndjo et al., 2019. namely three young bulls $(114.23 \pm 5.26 \mathrm{~kg})$ and three heifers $(95.37 \pm 4.65 \mathrm{~kg})$, of Lagune cattle breed were offered 1,000 seeds each of $A$. histrix and the percentages of seeds recovered were determined using a method similar to Houndjo et al. (2019b).

All dung produced by each cattle were collected at the end of each 24-hour period in plastic trays for six days, i.e., at 24, 48, 72, 96, 120 and $144 \mathrm{~h}$ after consuming the seeds. Total fresh dung of each animal were mixed and three, $200 \mathrm{~g}$ aliquots were sampled by collection time. One aliquot was retained for dry matter (DM) determination, one for seed recovery estimates of A. histrix, and another for germination assays. Two hundred grams faecal subsample for seed recovery estimates were immediately washed with running water through a series of two stacked sieves with decreasing apertures of $1 \mathrm{~mm}$ and $0.25 \mathrm{~mm}$ (Jones \& Bunch, 1977). The residuals were dried for approximately $24 \mathrm{~h}$ at $28{ }^{\circ} \mathrm{C}$ in a forced air oven to remove larger particles of digesta and undamaged seeds were separated and counted (Doucette et al., 2001). The average number of seeds retrieved from daily subsamples was extrapolated to the total daily dung amount per animal.

\subsection{Seed germination}

Germination testing. Experiments were performed in the Laboratory of Agrostology and Innovation of the University of Abomey-Calavi. Three replicates of a splitplot experiment were used with retention time $(24,48$, 72 and $96 \mathrm{~h}$ ) as the main plots in a randomized complete block design (RCBD), sex (male and female) as the subplots combined to give a total of eight treatments with 24 plots. Soil of the experimental site was collected and sieved and for each treatment and for each replicate, all seeds intact recovered per cattle (40.96 seeds) were placed on the surface of $150 \mathrm{~mm}$ diameter pots filled with sieved, sterilized sand and kept moist. The pots were kept in a shade house at ambient temperature (in the range of about $20-29^{\circ} \mathrm{C}$ ) and the number of seeds that germinated was recorded daily until 20 days. The germination of seeds retrieved from cattle dung was compared to the germination of seeds of seven other pre-planting seed treatments: (1) control (intact untreated seeds); (2) sandpaper (intact seeds plus mechanical scarification using sandpaper); and intact seeds were immersed in hot water $\left(80^{\circ} \mathrm{C}\right)$ for $2(3), 4(4), 6(5), 8(6)$, and $10 \mathrm{~min}(7)$. One hundred seeds were submitted for each pre-planting seed treatment and for each replicate (five replications per treatment), 20 seeds were placed on the surface of $150 \mathrm{~mm}$ diameter pots filled with sieved, sterilized sand and kept moist and the germination test was conducted using the standard procedure (ISTA, 1999). Seeds were considered germinated after root emergence (ISTA, 1999). Germinated seeds (germinable seeds) were counted and removed. At the end of the test seeds that 
had not germinated were categorized as hard or rotten seeds through examination by touching and piercing with a needle. Hard seeds could not be pierced with the needle (Hassen et al., 2004). Germination percentage (GP), germination speed (GS) and mean germination time (MGT) were also determined using the standard procedure mentioned by Houndjo et al. (2019b).

Seedling emergence from dung. In the third part the number of $A$. histrix seedlings emerged from intact (20.48 seeds tested per cattle) and crumbled faeces (20.48 seeds tested per cattle) was assessed using a method similar to Houndjo et al. (2019b). Three replicates of a split-plot experiment were used with retention time $(24,48,72$ and $96 \mathrm{~h}$ ) as the main plot in a randomized complete block design (RCBD), sex (male and female) as the subplot, dung form (intact and crumbled faeces) as the sub subplot combined to give a total of 16 treatments with 48 plots.

The germinable seeds, hard seeds and rotten seeds recovered were submitted, after arcsine transformation, to analysis of variance using Proc GLM of SAS (SAS, 2015) and all data were checked for normality. When Fisher's F values were significant at $p<0.05$, the analysis was continued using Tukey's test at the threshold of $p<0.05$ by comparing the means of the germination of seeds retrieved from cattle dung with the germination of seeds of seven other pre-planting seed treatments.

\section{RESULTS}

\subsection{Faeces recovery and number of seeds recovered from cattle}

Of the number of A. histrix seeds fed, $13.42 \pm 3.91 \%$ were recovered (Figure 1), and most seeds were recovered after 2 to 3 days.

\subsection{Seed germination after ingestion by cattle}

Percentage of germinated seeds of A.histrix from the seeds recovered after passage through digestive tract of cattle significantly decreased, as the retention time increased from $48 \mathrm{~h}(9.16 \%)$ to $96 \mathrm{~h}(1.25 \%)$ (Tukey test, $p<0.05$ ) (Table 2). Seeds recovered at $48 \mathrm{~h}$ after ingestion exhibited a significantly low level of germinable seeds (48.51 seeds), and rotten seeds (88.78 seeds) and a high level of hard seeds (336.50 seeds) (Tukey test, $p<0.05$ ) (Table 3).

\subsection{Effects of pre-planting seed treatment on germination parameters}

Compared to control seeds $(26 \pm 4.18 \%)$, the germination percentage was greatest for seeds from mechanical scarification with sandpaper (96\%) and

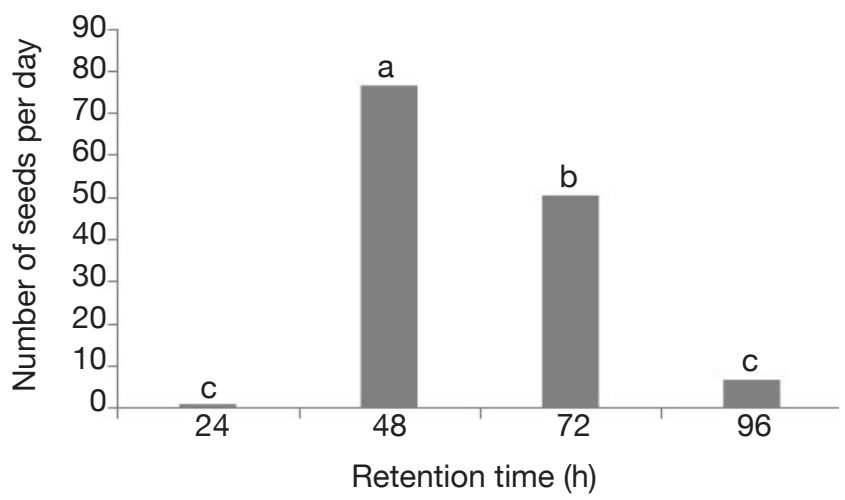

Figure 1. Number of seeds per head recovered from cattle faeces - Nombre de graines par tête récupérées dans les fèces de bovins.

Different letters indicate significant differences among number of seeds per head recovered from cattle faeces (Tukey test, $p<0.05)$ - des lettres différentes indiquent des différences significatives dans le nombre de graines par tête récupérées dans les fèces de bovins (test de Tukey, $\mathrm{p}<0,05$ ).

Table 2. Characteristics of seeds germination after passage through digestive tract of cattle and faeces (dry matter per cattle per day) - Caractéristiques de la germination des graines après passage dans le tube digestif des bovins et des fèces (matière sèche par bovin par jour).

\begin{tabular}{lllll}
\hline Retention time $(\mathrm{h})$ & $\begin{array}{l}\text { Percentage of } \\
\text { germinated seeds }(\%)\end{array}$ & $\begin{array}{l}\text { Mean germination } \\
\text { time (day) }\end{array}$ & $\begin{array}{l}\text { Germination speed } \\
(\text { seed/day) }\end{array}$ & Faeces dry matter $(\mathrm{g})$ \\
\hline $24 \mathrm{~h}$ & $0.00^{\mathrm{b}}$ & $0.00^{\mathrm{b}}$ & $0.00^{\mathrm{b}}$ & $227.09^{\mathrm{a}}$ \\
\hline $48 \mathrm{~h}$ & $9.16^{\mathrm{a}}$ & $4.30^{\mathrm{a}}$ & $0.48^{\mathrm{a}}$ & $172.17^{\mathrm{a}}$ \\
\hline $72 \mathrm{~h}$ & $6.66^{\mathrm{a}}$ & $4.95^{\mathrm{a}}$ & $0.36^{\mathrm{a}}$ & $224.67^{\mathrm{a}}$ \\
\hline $6 \mathrm{~h}$ & $1.25^{\mathrm{b}}$ & $0.79^{\mathrm{b}}$ & $0.05^{\mathrm{b}}$ & $256.61^{\mathrm{a}}$ \\
\hline Overall mean & 4.27 & 2.51 & 0.226 & 220.13 \\
\hline
\end{tabular}

For the same column, means followed by the same lower letter are not significantly different (Tukey test, $p<0.05)-$ Pour la même colonne, les moyennes suivies de la même lettre en minuscule ne sont pas significativement différentes (test de Tukey, $\mathrm{p}<0,05)$. 
Table 3. Distribution of germinating, hard and rotten seeds after excreted seeds in $1,000 \mathrm{~g}$ dry matter faeces per day - Distribution des graines germantes, dures et pourries après excrétion des graines dans $1000 \mathrm{~g}$ de matières fécales par jour.

\begin{tabular}{lcccc}
\hline Retention time $(\mathrm{h})$ & $\begin{array}{l}\text { Excreted seeds in } \\
\mathbf{1 , 0 0 0} \mathbf{g} \text { DM }\end{array}$ & Germinable seeds & Hard seeds & Rotten seeds \\
\hline $24 \mathrm{~h}$ & $2.70^{\mathrm{c}}$ & $0.00^{\mathrm{b}}$ & $0.9^{\mathrm{b}}$ & $1.84^{\mathrm{b}}$ \\
\hline $8 \mathrm{~h}$ & $473.80^{\mathrm{a}}$ & $48.51^{\mathrm{a}}$ & $336.50^{\mathrm{a}}$ & $88.78^{\mathrm{a}}$ \\
$72 \mathrm{~h}$ & $278.00^{\mathrm{b}}$ & $17.48^{\mathrm{b}}$ & $240.70^{\mathrm{a}}$ & $19.83^{\mathrm{b}}$ \\
$96 \mathrm{~h}$ & $25.50^{\mathrm{c}}$ & $0.76^{\mathrm{b}}$ & $23.30^{\mathrm{b}}$ & $1.44^{\mathrm{b}}$ \\
\hline Overall mean & 195.01 & 16.68 & 150.34 & 27.97 \\
\hline
\end{tabular}

For the same column, means followed by the same lower letter are not significantly different (Tukey test, $p<0.05)-$ pour la même colonne, les moyennes suivies de la même lettre en minuscule ne sont pas significativement différentes (test de Tukey, $\mathrm{p}<0,05)$. 0: in these time periods, no seeds were recovered - dans ces périodes, aucune graine n'a été récupérée.

2 min heat treatment $(86 \%)$, and least for seeds from passage through the digestive system of cattle $(4.27 \%)$ (Tukey test, $p<0.05$ ) (Figure 2, Tables 2 and 4). Again germination speed of seeds immersed in hot water for $2 \mathrm{~min}$ is the highest 8.32 seeds/day, and lowest for seeds recovered from the faeces $(0.23$ seeds/ day) (Tables 2 and 4). The fastest (3.03 day) mean germination time was recorded in the seeds immersed in hot water for 2 min and the slowest (5.12 day) was recorded in the control (Tables 2 and $\mathbf{4}$ ).

\subsection{Establishment in trays of $\boldsymbol{A}$. histrix seedlings from faeces}

The number of seedlings emerging out of crumbled faeces (3.52 plants per cattle) was significantly higher $(p<0.05)$ compared to seedling emergence out of intact faeces ( 1.35 plants per cattle) but remained very low.

\section{DISCUSSION}

A small percentage of ingested seeds of A. histrix passes through the Lagune cattle gastro-intestinal tract. The percentage of A.histrix seeds retrieved $(13.42 \%)$ from cattle dung is similar to those obtained for other herbaceous and shrub species eaten by cattle (6.2-80\%) (Gardener et al., 1993; Houndjo et al., 2019a). Therefore it is suggested that Lagune cattle are potential vectors of $A$. histrix. However cattle digested considerably higher amounts (86.58\%) of A. histrix seeds. In practice (animal nutrition), legume seeds have long been considered as a source of high quality protein for grazing ruminants. Percentage of germinated seeds of A.histrix significantly decreased, as the retention time increased from $48 \mathrm{~h}(9.16 \%)$ to $96 \mathrm{~h}(1.25 \%)$. These results corroborated the findings of Rahimi et al. (2016), who reported that the viability of excreted seeds declines with the length of time seeds spend in the digestive tract. However consumption of seeds by cattle is not effective for increasing the germinability of A. histrix seeds, as we estimate that $4.27 \%$ (5.73 seeds) of A. histrix seeds would still be potentially able to germinate from the total recovered seeds (134.2 seeds). Seeds recovered at $48 \mathrm{~h}$ after ingestion exhibited a

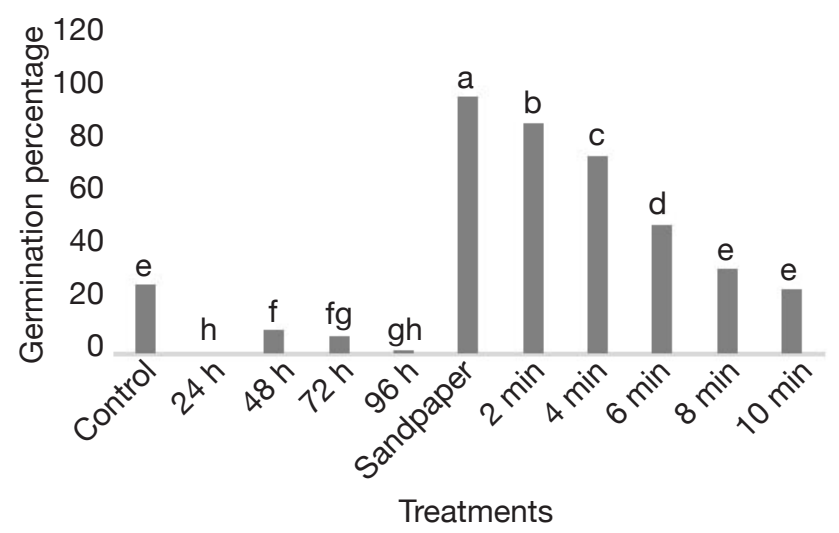

Figure 2. Germination percentage of treated Aeschynomene histrix seeds - Pourcentage de germination des graines d'Aeschynomene histrix traitées.

Control: intact untreated seeds; seeds recovered in the cattle trial with their retention time $(24,48,72$ and $96 \mathrm{~h})$; sandpaper: mechanical scarification using sandpaper; seeds were immersed in hot water $\left(80^{\circ} \mathrm{C}\right)$ for $2,4,6,8$, and 10 min - contrôle : graines intactes non traitées; les graines récupéées dans l'essai sur les bovins avec leur temps de rétention (24, 48, 72 et $96 \mathrm{~h})$; papier à scarifier : scarification mécanique à l'aide du papier à scarifier ; les graines ont été immergées dans de l'eau chaude $\left(80^{\circ} \mathrm{C}\right)$ pendant 2, 4, 6, 8 et $10 \mathrm{~min}$ ) ; different letters indicate significant differences among germination percentage of treated A. histrix seeds (Tukey test, $p<0.05)$ - des lettres différentes indiquent des différences significatives entre les pourcentages de germination des graines d'A. histrix traitées (test de Tukey, $\mathrm{p}<0,05$ ). 
Table 4. Characteristics of seeds germination for the various other pre-planting seed treatments - Caractéristiques de la germination des semences pour les différents autres traitements pré-semis.

\begin{tabular}{llcccc}
\hline Treatments & $\begin{array}{l}\text { Germinable seeds } \\
(\%)\end{array}$ & Hard seeds $(\%)$ & Rotten seeds (\%) & $\begin{array}{l}\text { Mean germination } \\
\text { time (day) }\end{array}$ & $\begin{array}{l}\text { Germination } \\
\text { speed (seed/day) }\end{array}$ \\
\hline Control & $26.00^{\mathrm{e}}$ & $54.00^{\mathrm{a}}$ & $20.00^{\mathrm{d}}$ & $5.12^{\mathrm{a}}$ & $1.19^{\mathrm{d}}$ \\
\hline Sandpaper & $96.00^{\mathrm{a}}$ & $0.00^{\mathrm{c}}$ & $4.00^{\mathrm{e}}$ & $3.24^{\mathrm{b}}$ & $6.26^{\mathrm{ab}}$ \\
$2 \mathrm{~min}$ & $86.00^{\mathrm{b}}$ & $8.60^{\mathrm{b}}$ & $5.40^{\mathrm{e}}$ & $3.03^{\mathrm{b}}$ & $8.32^{\mathrm{a}}$ \\
$4 \mathrm{~min}$ & $74.00^{\mathrm{c}}$ & $9.80^{\mathrm{b}}$ & $16.20^{\mathrm{de}}$ & $3.80^{\mathrm{ab}}$ & $4.90^{\mathrm{bc}}$ \\
$6 \mathrm{~min}$ & $48.00^{\mathrm{d}}$ & $10.00^{\mathrm{b}}$ & $42.00^{\mathrm{c}}$ & $4.14^{\mathrm{ab}}$ & $3.07^{\mathrm{cd}}$ \\
$8 \mathrm{~min}$ & $32.00^{\mathrm{e}}$ & $12.00^{\mathrm{b}}$ & $56.00^{\mathrm{b}}$ & $3.99^{\mathrm{ab}}$ & $2.03^{\mathrm{d}}$ \\
$10 \mathrm{~min}$ & $24.00^{\mathrm{e}}$ & $8.00^{\mathrm{b}}$ & $68.00^{\mathrm{a}}$ & $3.97^{\mathrm{ab}}$ & $1.54^{\mathrm{d}}$ \\
\hline Overall mean & 55.14 & 14.62 & 30.22 & 3.90 & 3.90 \\
\hline
\end{tabular}

For the same column, means followed by the same lower letter are not significantly different (Tukey test, $p<0.05)-$ pour la même colonne, les moyennes suivies de la même lettre en minuscule ne sont pas significativement différentes (test de Tukey, $\mathrm{p}<0,05)$.

significantly high degree of hard seeds (336.50 seeds) and a low level of germinable seeds (48.51 seeds), and rotten seeds (88.78 seeds) (Tukey test, $p<0.05$ ). In the Guinean Soudanian agroecological zone of Benin, A. histrix hard seeds present in the soil seed bank could be softened by temperature fluctuation during the dry season between August to mid-September and December to March (Jaganathan et al., 2018). Overall germination percentage of the intact untreated seeds $(26.00 \%)$ was significantly higher (Tukey test, $p<0.05$ ) than that of seeds recovered from faeces $(4.27 \%)$. This is in agreement with previous studies on herbaceous seeds dispersal via endozoochory (Shayo \& Uden, 1998; Razanamandranto et al., 2004; Viero et al., 2018). The germination percentage was greatest for seeds from mechanical scarification with sandpaper $(96 \%)$, intermediate for seeds from hot water scarification $(52.80 \%)$, and least for seeds from passage through cattle tracts $(4.27 \%)$ (Tukey test, $p<$ $0.05)$. Mechanical scarification has a positive effect on breaking physical dormancy because sandpapering may have cracked the lignified palisade cells and consequently the seed could absorb water and oxygen, swell and germinate (Yildiztugay \& Kucukoduk, 2012). Hot water scarification at 2 min soaking significantly increased germination percentage of A. histrix from $26 \%$ (intact untreated seeds) to $86 \%$ but with the longer time of exposure, the values of the germination speed decreased. As it is desirable, to sow pastures with A. histrix seeds, the use of mechanical scarification using sandpapering or hot water scarification at $80{ }^{\circ} \mathrm{C}$ during 2 min may be more beneficial, giving high germination percentage and uniform germination. The result demonstrates that breaking down the dung doubled seedling emergence (Mancilla-Leytón et al., 2012; Eichberg et al., 2016). However it would be necessary to evaluate the palatability of these seeds under field conditions and the germination and establishment of these species in faeces in the field.

\section{CONCLUSIONS}

The passage of $A$. histrix seeds through the digestive system of Lagune cattle reduces its germination, and they presented inferior germination compared to seeds from mechanical scarification with sandpaper and seeds from hot water scarification. As it is desirable, to break dormancy of $A$. histrix seeds, the use of mechanical scarification using sandpapering or hot water scarification at $80^{\circ} \mathrm{C}$ during 2 min may be more beneficial giving high germination percentage and uniform germination.

\section{Acknowledgements}

This research was supported by funding from the International Foundation for Science (research grant agreement NO. I-1-C-6195-1).

\section{Bibliography}

Adjolohoun S., 2008. Yield, nutritive value and effects on soil fertility of forage grasses and legumes cultivated as ley pastures in the Borgou region of Benin. Thèse de doctorat: Faculté universitaire des Sciences agronomiques de Gembloux (Belgique).

Baskin C.C. \& Baskin J.M., 1998. Seeds: ecology, biogeography, and evolution of dormancy and germination. Elsevier.

Bhatt R.K., Tripathi R.K., Tiwari H.S., Rajput D.S. \& Chandra A., 2008. Effect of dormancy breaking treatments on seed germination of Stylosanthes species. Indian J. Plant Physiol., 13(1), 60-65. 
Campos C.M.et al.,2008.Endozoochory by native and exotic herbivores in dry areas: consequences for germination and survival of Prosopis seeds. Seed Sci.Res., 18(2), 91100, doi.org/10.1017/s0960258508940344

Doucette K.M., Wittenberg K.M. \& McCaughey W.P., 2001. Seed recovery and germination of reseeded species fed to cattle. J. Range Manage., 54(5), 575-581, doi.org/10.2307/4003587

Eichberg C. et al., 2016. The anthelmintic ingredient moxidectin negatively affects seed germination of three temperate grassland species. Plos One, 11(11), e0166366, doi.org/10.1371/journal.pone.0166366

Gardener C.J., McIvor J.G. \& Jansen A., 1993. Passage of legume and grass seeds through the digestive tract of cattle and their survival in faeces. J. Appl. Ecol., 30(1), 63, doi.org/10.2307/2404271

Hassen A., Pieterse P.A. \& Rethman N.F.G., 2004. Effect of pre-planting seed treatment on dormancy breaking and germination of Indigofera accessions. Trop. Grassl., 38(3), 154-157.

Houndjo B.D.M. et al., 2019a. Effects of seeds ingestion by Lagune cattle and other pre-planting treatments on the germinability of Centrosema pubescens Benth seeds in Soudanian region of Benin (West Africa). Afr. J. Agric. Res., 14(20), 850-861.

Houndjo B.D.M. et al., 2019b. Growth and seed yield response of Aeschynomene histrix to cattle manure and plant row spacing in Southern Benin. Int. J. Sci. Res., 8(3), 183-190.

ISTA (International Seed Testing Association), 1999. International rules for seed testing. Seed Sci. Technol., 27(Suppl), 1-333.

Jaganathan G.K., $\quad$ Yule K.J. \& Biddick M., 2018. Determination of the water gap and the germination ecology of Adenanthera pavonina (Fabaceae, Mimosoideae); the adaptive role of physical dormancy in mimetic seeds. AoB Plants, 10(5), ply048, doi. org/10.1093/aobpla/ply048

Jones R.M. \& Bunch G.A., 1977. Sampling and measuring the legume seed content of pasture soils and cattle faeces. Brisbane, Australia: CSIRO.

Mancilla-Leytón J.M., Fernández-Alés R. \& Vicente A.M., 2012. Low viability and germinability of commercial pasture seedsingested by goats.SmallRumin.Res.,107(1), 12-15, doi.org/10.1016/j.smallrumres.2012.04.001

Merkel U. et al., 2000. Characterization of a collection of Aeschynomene histrix in subhumid Nigeria. J.Agric. Sci., 134(3), 293-304, doi.org/10.1017/s0021859699007546

Ocumpaugh W.R. \& Swakon D.H.D., 1993. Simulating grass seed passage through the digestive system of cattle: a laboratory technique. Crop Sci., 33(5), 1084-1090, doi. org/10.2135/cropsci1993.0011183x003300050041x

Pakeman R.J., Digneffe G. \& Small J.L., 2002. Ecological correlates of endozoochory by herbivores. Funct. Ecol., 16(3), 296-304, doi.org/10.1046/j.13652435.2002.00625.x

Peters M., Tarawali S.A. \& Alkanper J., 1994. Evaluation of tropical pasture legumes for fodder banks in subhumid Nigeria. 2. Accessions of Aeschynomene histrix, Centrosema acutifolium, C.pascuorum, Stylosanthes guianensis and S. hamata. Trop. Grassl., 28, 74-79.

Rahimi S., Mashhadi H.R., Banadaky M.D. \& Mesgaran M.B., 2016. Variation in weed seed fate fed to different Holstein cattle groups. Plos One, 11(4), e0154057, doi.org/10.1371/journal.pone.0154057

Razanamandranto S., Tigabu M., Neya S. \& Odén P.C., 2004. Effects of gut treatment on recovery and germinability of bovine and ovine ingested seeds of four woody species from the Sudanian savanna in West Africa. Flora Morphol. Distrib. Funct. Ecol. Plants, 199(5), 389-397, doi.org/10.1078/0367-2530-00167

Rusdy M., 2015. Enhancing germination in seeds of Centrosema pubescens. Int. J. Sci. Res., 5(10), 1-4.

SAS I.I., 2015. SAS/STAT user's guide. Cary, NC, USA: SAS Institute Inc.

Shayo C.M. \& Uden P., 1998. Recovery of seed of four African browse shrubs ingested by cattle, sheep and goats and the effect of ingestion, hot water and acid treatment on the viability of the seeds. Trop. Grassl., 32, 195-200.

Tarawali G., Mohamed-Saleem M.A. \& von Kaufmann R., 1988. Legume-based cropping: a possible remedy to land tenure constraint to ruminant production in the sub humid zone of Central Nigeria. In : Dzowela B.H., ed. Proceedings of the third workshop, African forage plant genetic resources, evaluation of forage germplasm and extensive livestock production systems, April 27-30, 1987, International Conference Centre, Arusha, Tanzania. Addis Ababa, Ethiopia: International Livestock Centre for Africa, 417-429.

Viero J.L.C. et al., 2018. Endozoochorous dispersal of seeds of weedy rice (Oryza sativa L.) and barnyardgrass (Echinochloa crus-galli L.) by cattle. Ciênc. Rural, 48(8), doi.org/10.1590/0103-8478cr20170650

Yildiztugay E. \& Kucukoduk M., 2012. Dormancy breaking and germination requirements for seeds of Sphaerophysa kotschyana Boiss. J. Glob. Biosci., 1, 20-27.

(26 ref.) 